\title{
UTOPIA DIVIDIDA A CRISE DO PCB (1979-1992)'
}

Fabricio Pereira da Silva

Mestre em História/UFRJ e doutorando em Ciência Política/Iuperj

\section{Resumo}

Esse artigo analisa a crise e divisão do Partido Comunista Brasileiro (PCB), processo que teve seus acontecimentos decisivos entre 1979 e 1992. Enquanto suas propostas para a redemocratização brasileira em boa parte foram vitoriosas (superação processual e pacífica da ditadura através da formação de uma ampla frente democrática intraclassista), o PCB encontrou sua maior crise.

\section{Pallavras-chaves}

Partido Comunista Brasileiro • socialismo • redemocratização brasileira.

\section{Abstract}

This article deals with the crisis of the Brazilian Communist Party - henceforth, PCB - a process which has its decisive moments between 1979 and 1992. Despite the fact that its proposals for the Brazilian re-democratization were successful in a great deal (peaceful and processual overcoming of the dictatorship through the construction of a wide democratic intra-class coalition), the PCB met its greatest crisis.

\section{Keywords}

Brazilian Communist Party • socialism • brazilian re-democratization.

\footnotetext{
${ }^{1}$ Este artigo é parte de dissertação de mestrado que contou com o apoio do Conselho Nacional de Desenvolvimento Científico e Tecnológico - CNPq para sua realização.
} 


\section{Apresentação}

Este artigo aborda o Partido Comunista Brasileiro (PCB) ao longo da abertura e transição democrática. O PCB oscilou, ao longo de sua trajetória, entre a adesão a um projeto revolucionário e tendências mais reformadoras em sua praxis e objetivos; entre os exemplos internacionais do "socialismo real" e a realidade brasileira; entre a opção de se constituir num partido de massas, ou assumir o papel de "partido de quadros", tendo por objetivo o "assalto" ao poder; entre a via pacífica ao socialismo e a insurrecional. No período entre 1979 e 1992, o PCB perdeu definitivamente seu papel hegemônico e referencial no campo das esquerdas para uma nova agremiação (o Partido dos Trabalhadores - PT, fundado em 1980) e assistiu à erosão de suas bases sindicais. Na seqüência, com a legalidade em 1985, depois de trinta e oito anos, os pecebistas foram obrigados a amargar ínfimos resultados eleitorais. Tudo isso à revelia da vitória do caminho defendido pelo partido (e combatido por outros setores das esquerdas) para a superação da ditadura: pacífico, negociado, progressivo. Tiveram que conviver com crises internas que custaram esporádicas cisões e com a crise que acometeu o "mundo socialista” e o pensamento marxista em geral. Tudo isso culminou na autoproclamada extinção do PCB.

Nas próximas páginas exponho a questão que norteia o artigo e as três hipóteses elaboradas para respondê-la. Apresento na seqüência os principais movimentos do partido no período estudado e os fatores que, em minha avaliação, mais contribuíram para sua crise. A narrativa será entremeada por trechos de entrevistas ${ }^{2}$ e por passagens retiradas de documentos, revistas e jornais publicados pelo partido ou por grupos organizados em torno de suas disputas internas. ${ }^{3}$

\footnotetext{
${ }^{2}$ Colhi depoimentos de militantes dos diferentes grupos que tiveram peso no PCB no período analisado. Optei majoritariamente por militantes representativos da vida partidária - entrevistando também alguns militantes de base, o que permitiu uma visão mais complexa do objeto. Foram entrevistados Geraldo Rodrigues dos Santos, Gilvan Cavalcanti Melo, Givaldo Siqueira, Leandro Konder, Severino Theodoro de Mello, Zuleide Faria de Melo e Zuleika Alambert. Ao analisar os depoimentos, considerei que histórias de vida são reconstruções a posteriori de memória e identidade, realizadas através de diversas "negociações" e seleções, apresentando "esquecimentos", desencontros e "não-ditos" (POLLACK, Michael. Memória, esquecimento, silêncio. Estudos Históricos, Rio de Janeiro: vol. 2, n. ${ }^{\circ}$ 3, 1989.

${ }^{3}$ Em termos de imprensa partidária, pesquisei o último ano da fase "oficial" do jornal Voz Operária (1979), o jornal Voz da Unidade (1980-1991) e a revista Novos Rumos (1986-1991). Quanto à imprensa publicada por grupos oposicionistas ou dissidentes, destaco a última fase do jornal Voz Operária (1980-1982), editado pelos “prestistas”, e a revista Presença (1983-1992) dos "renovadores", entre outras.
} 


\section{0 paradoxo}

A crise e a “dissolução” do PCB causaram perplexidade em qualquer observador que soubesse da importância daquela agremiação na história brasileira ao longo da maior parte do século XX. Um partido que chegou a ser hegemônico nas esquerdas e nos movimentos sociais, que participou em vários momentos da chamada "alta política”, sem nem mesmo possuir existência legal na maior parte do tempo, passou por um processo de definhamento, terminando "dissolvido" - na verdade dividido. E mais: tal processo teve sua fase decisiva no momento em que as propostas do PCB para a redemocratização brasileira se tornaram majoritárias no campo oposicionista e foram finalmente vitoriosas - ainda que por caminhos tortuosos, diversos dos propugnados pelo partido.

Para ajudar a compreender esse aparente paradoxo, pode-se lançar mão da seguinte chave explicativa: o Brasil estava completando naquele momento sua modernização capitalista, por meio de uma "revolução passiva” - e a ditadura de caráter "modernizador autoritário" constituiu-se como um passo fundamental nesse caminho. Antonio Gramsci lançou mão do conceito de "revolução passiva” para compreender a possibilidade de uma sociedade passar a um novo estágio de organização sem uma revolução aberta. Tal fenômeno se daria de uma maneira processual e em certos aspectos incompleta, a partir de um grande equilíbrio na luta de classes.

A sociedade brasileira passava, através desse processo, por profundas transformações, tornando-se assim mais complexa, com o desenvolvimento de uma pujante sociedade civil. Nos dizeres de Gramsci, tornava-se uma sociedade “ocidentalizada”,

onde se dá uma relação mais equilibrada entre sociedade civil e sociedade política, ou seja, onde se realizou concretamente a "ampliação" do Estado. (...) No "Ocidente", (...) as batalhas deveriam ser travadas inicialmente no âmbito da sociedade civil, visando à conquista de posições e de espaços ("guerra de posição"), da direção político-ideológica e do consenso dos setores majoritários da população, como condição para o acesso ao poder de Estado e para sua posterior conservação. ${ }^{4}$

${ }^{4}$ COUTINHO, Carlos Nelson. Gramsci - um estudo sobre seu pensamento político. Rio de Janeiro: Civilização Brasileira, 1999, p. 147. 
Nesse novo contexto, teriam mais chance de êxito organizações partidárias adaptadas à nova realidade: mais democráticas, desburocratizadas, plurais.

Partindo dessa premissa eu recorro a três hipóteses.

A hipótese central aponta a persistência de concepções e práticas burocráticas "centralizadoras" e mesmo antidemocráticas no PCB, quando o país completava seu processo de modernização capitalista pela "via passiva”, como fator determinante para a crise geral que acometeu o partido. Tal situação levou a uma progressiva inadequação deste à sociedade que pretendia transformar, à baixa representação pecebista entre os setores modernos do “novo” movimento sindical e à paralisia interna derivada de sua progressiva divisão. As fontes utilizadas permitem observar a reprodução de tais procedimentos e concepções centralistas e antidemocráticas no PCB. Considerando-se a conclusão naquele momento do longo processo de modernização capitalista do Brasil, ${ }^{5}$ é possível relacionar os dois fatores. Tal combinação entre entorno cambiante e ator político cristalizado teria levado à crescente fraqueza (seja orgânica, eleitoral, propositiva), paralisia e esfacelamento do PCB, levando-se em conta a redução de sua inserção entre os setores organizados mais modernos da classe trabalhadora, sua dificuldade de implantação em regiões de desenvolvimento capitalista mais pujante, o congelamento em patamares muito baixos de seu caudal eleitoral, a incapacidade de dar respostas às transformações do Brasil, do capitalismo internacional, do socialismo real. Análises quantitativas acerca da composição social e espacial do partido provavelmente corroborariam tal hipótese e devem ser objeto de futuras pesquisas.

Há, por fim, duas hipóteses secundárias. Uma relaciona a crise do PCB às dificuldades do partido em lidar com a transição negociada (à qual terminou atrelado em posição subalterna) da forma como se deu: uma transição "fraca”, com predominância dos interesses conservadores. Enquanto isso, o PT, assumindo posição claramente contrária àquele processo, viabilizou-se enquanto força hegemônica nas esquerdas e no movimento sindical. A outra aponta para a crise do "mundo socialista" que também jogou importante papel no processo, legitimando e reforçando tendências já presentes no PCB.

\footnotetext{
${ }^{5}$ Cf., COUTINHO, Carlos Nelson. Democracia e socialismo. São Paulo: Cortez, 1992; VIANNA, Luiz Werneck. A revolução passiva - iberismo e americanismo no Brasil. Rio de Janeiro: Revan, 1997.
} 


\section{Luta pela democracia, democracia em debate - o PCB na "abertura" (1979-1983)}

Praticamente desde o princípio da ditadura, o PCB se definiu pelo enfrentamento pacífico àquele regime, adotando "a tática da 'Frente Democrática'. Os pecebistas deveriam se aliar a todos os que se opunham à ditadura. $\mathrm{O}$ partido defendia que a derrubada do regime deveria se dar através de soluções politicamente negociadas". ${ }^{6}$ A gênese dessa política foi assim descrita por um entrevistado:

O partido convocou um congresso para reafirmar a nossa linha política, em cima de cisões, de quedas, o pessoal saindo para o exílio... Então, a gente tentou organizar o [VI] congresso que foi realizado em 1967 e que referendou toda a nossa política de frente democrática, da questão já da Anistia, da Constituinte, nos documentos de 1967 já está explicitada toda essa política de abertura política, de se trabalhar através da sociedade, para "derrotar" politicamente a ditadura, e não para "derrubar" a ditadura. A "derrubada" significa a luta armada, e a "derrota" significava para nós o envolvimento da sociedade, dos movimentos políticos, da população no sentido de isolar a ditadura e dar uma saída até negociada, como na realidade aconteceu. ${ }^{7}$

Tal política, de um modo geral, manteve-se ao longo de toda a ditadura, porém seu percurso não foi tão linear quanto a memória pode sugerir. Sabe-se que essa linha política foi aprovada com grandes dificuldades em 1967 (à custa de uma grande perda de contingentes na agremiação) e que permaneceu sendo questionada por alguns, até ser abertamente atacada por Luiz Carlos Prestes e seu grupo já no exílio - e ruidosamente no retorno ao Brasil. O depoimento a seguir sugere a permanência de uma visão crítica à "via pacífica" ao longo de todo o período: "Eu sempre achei que seria guerrilheira, sempre achei. Mas nunca fui. (...) como o PCB jamais optou pela luta armada, eu jamais saí... Mas por outro lado, eu me impus (o que não é tão fácil) uma disciplina partidária, é também assim: num tipo de divergência, ou você é absolutamente disciplinado ou não sobrevive”. ${ }^{8}$

\footnotetext{
${ }^{6}$ PANDOLFI, Dulce. Camaradas e companheiros: história e memória do PCB. Rio de Janeiro: Relume-Dumará, 1995, p. 206-207.

${ }^{7}$ Gilvan Cavalcanti Melo, depoimento cedido ao autor em 30 de julho de 2003, no Rio de Janeiro (RJ).

${ }^{8}$ Zuleide Faria de Melo, depoimento cedido ao autor em 21 de abril de 2004, no Rio de Janeiro (RJ).
} 
Os anos 1970 foram especialmente difíceis para o PCB. Se antes o partido sofreu uma verdadeira "sangria" de seus quadros para as organizações da "esquerda armada", a partir de 1974 se tornou (desmanteladas aquelas organizações) o alvo preferencial do aparelho repressivo. O princípio do complexo processo de abertura, a partir do governo de Ernesto Geisel, coincide com um aumento da perseguição aos pecebistas. O partido se viu obrigado praticamente a recomeçar. No exterior, seus dirigentes esforçavam-se para manter a unidade, enquanto no Brasil o partido buscava reorganizar-se em cada estado.

O período estudado começa com a extinção do Ato Institucional n. ${ }^{\circ} 5$ e a decretação da Anistia - o que abriu novos espaços para a atuação do PCB e permitiu a volta dos dirigentes exilados na Europa. No entanto, deve-se recordar que os pecebistas eram obrigados ainda a conviver com a ilegalidade e a repressão (ainda que numa intensidade baixa se comparada aos anos anteriores). O partido reconhecia que o quadro tinha mudado, mas não o suficiente para que sua linha política devesse sofrer alguma inflexão profunda - devendo continuar assim atrelado na prática ao Movimento Democrático Brasileiro (MDB - e, a partir de 1979, Partido do Movimento Democrático Brasileiro, PMDB). Os pecebistas atuaram ao longo de todo o período ditatorial naquele partido e alguns chegaram a disputar e conquistar cargos eletivos pela legenda. ${ }^{9}$

No entanto, não era isso o que pensavam amplos setores do quadro partidário e, a partir de 1979, iniciou-se a atuação pública dos autodenominados "renovadores" - boa parte dos intelectuais de renome do partido que exigiam a democratização das instâncias partidárias e o que classificavam como o "arejamento" do ideário comunista através da concepção da "democracia como valor universal". E também dos chamados "prestistas", agrupados em torno de Prestes, que pugnavam pelo "resgate do caráter revolucionário" pecebista e por uma postura de enfrentamento aberto em relação à ditadura.

Os primeiros defendiam que a luta pela democracia não deveria ser encarada como um objetivo tático (luta por um espaço mais propício para a atuação do partido), mas estratégico, pois seria indispensável na formação de elementos necessários ao desenvolvimento socialista. Além disso, “[d]iscordavam da visão 'etapista' do processo revolucionário e consideravam equivocada a proposta de revolução nacional-democrática, por pressupor uma subordinação da questão

\footnotetext{
${ }^{9} \mathrm{O}$ papel dos pecebistas na formatação do MDB efetivamente como uma frente oposicionista ainda está por ser mais bem estudado.
} 
democrática à questão nacional". ${ }^{10}$ Já os segundos seguiam de perto as críticas apresentadas por Prestes em sua Carta aos comunistas, de 1980: "Um partido comunista não pode, em nome de uma suposta democracia abstrata e acima das classes, abdicar de seu papel revolucionário e assumir o freio do movimento popular, de fiador de um pacto com a burguesia, em que sejam sacrificados os interesses e as aspirações dos trabalhadores". ${ }^{11}$

Ambos os grupos já vinham dando sinais de vida nos anos anteriores e, especificamente, os problemas entre Prestes e o restante da direção se manifestaram no exílio, mas sem o conhecimento das bases do partido. No entanto, somente agora se iniciava a disputa aberta em torno da linha política e do poder partidário. Travou-se, então, uma das disputas internas mais difíceis da história do partido que foi "resolvida" da maneira tradicional entre os pecebistas. Afastadas ou isoladas as dissidências ditas “à esquerda” e “à direita”, emergiu vitorioso um grupo um tanto indefinido que se identificou basicamente a partir de sua contraposição a "prestistas" e "renovadores", simbolizando um "justo centro" e buscando representar as propostas que vinham sendo defendidas pelo partido desde o congresso anterior, que avaliaram como corretas até aquele momento. Em especial, afirmaram simbolizar a maioria dos pecebistas. Esse grupo, formado pela maior parte do Comitê Central mantido ao longo da ditadura, pelos parlamentares pecebistas eleitos em 1982 através da legenda peemedebista e, a partir de 1986, pela pecebista, comandaria o partido até decidir por sua extinção em 1992.

Na prática, o partido seguiu uma trajetória marcada por certa dubiedade, buscando equilibrar-se entre o necessário enfrentamento com o regime e o sempre presente temor de um retrocesso. Evitava-se o enfrentamento aberto e a radicalização do discurso - o que, somado ao já citado temor de um retrocesso ditatorial, fez com que a atuação pecebista de um modo geral parecesse, a diversos setores das esquerdas, mais do que nunca excessivamente "reformista". O partido caracterizava o Brasil como um país capitalista industrial-agrário, com nível médio de desenvolvimento das forças produtivas, emergente nas condições da crise geral do capitalismo, da internacionalização e da interdependência do processo econômico mundial hierarquizado pelo imperialismo (...). O capitalismo brasileiro, monopolista e integrador do latifúndio, tem como característica

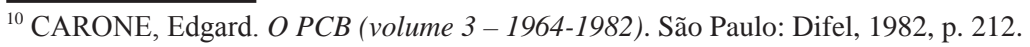

${ }^{11}$ PRESTES, Luiz Carlos. Carta aos comunistas. Apud PANDOLFI, Dulce, op. cit., p. 220.
} 
fundamental a sua dependência ao imperialismo (em especial o norte-americano) e articulou organicamente os mecanismos deste, dos monopólios e do latifúndio com os do Estado. ${ }^{12}$

Tal análise do capitalismo brasileiro como monopolista, relacionado intrinsecamente ao imperialismo e com resquícios pré-capitalistas (a presença do latifúndio) levou à definição do processo revolucionário como "antiimperialista, antimonopolista e antilatifundiário":

no campo dos exploradores destacam-se o imperialismo (...), os monopólios e o latifúndio, articulados organicamente com o Estado. Eles são os principais exploradores e opressores não apenas do proletariado, mas ainda dos camponeses e das camadas médias urbanas - isto é, do povo brasileiro -, e oprimem inclusive a burguesia não-monopolista. O imperialismo, porém, limita o próprio desenvolvimento de grupos monopolistas brasileiros e possui conflitos também com interesses latifundiários. A batalha antiimperialista, por isto mesmo, está no centro da luta dos comunistas. O imperialismo responde, no Brasil como em todo o mundo, em primeiro lugar pela exploração econômica e pela opressão social e política. ${ }^{13}$

De pouco adiantava a reiterada afirmação da centralidade da "luta pela conquista e ampliação contínua da democracia e as transformações econômico-sociais necessárias à sua conquista, consolidação e avanço, na medida em que o imperialismo e a reação interna, para garantirem sua dominação, concentram-se principalmente na supressão ou restrição da democracia”. ${ }^{14}$ Não adiantava também inverter a fórmula que traduzia o caráter da revolução brasileira - de "nacional e democrática" para "democrática e nacional". Na essência, a questão nacional mantinha sua primazia sobre a questão democrática. A centralidade pertencia à luta contra o imperialismo, o que favorecia um conteúdo nacionalista e permitia a aliança com setores burgueses (na prática uma reafirmação da velha fórmula da "burguesia nacional"). Por mais que se defendesse também que a contradição entre burguesia e proletariado já havia

\footnotetext{
${ }^{12}$ PARTIDO COMUNISTA BRASILEIRO. Uma alternativa democrática para a crise brasileira. São Paulo: Novos Rumos, 1984, p. 127-128.

${ }^{13}$ Ibid., p. 156-157.

${ }^{14}$ Ibid., p. 158.
} 
assumido a centralidade no processo revolucionário brasileiro, na prática esse fator acabava secundarizado. O PCB permanecia com dificuldades de colocar o socialismo na ordem-do-dia.

A luta contra a ditadura avançava da forma que os pecebistas propunham. Eles não conseguiam, porém, traduzir aquele momento favorável à sua política em fortalecimento orgânico e influência social. Pelo contrário: perdiam progressivamente seu espaço entre os setores progressistas organizados da sociedade e no próprio campo das esquerdas. A esse respeito, é necessário comentar mais detidamente o surgimento no período de "setores modernos" do sindicalismo, responsáveis pela retomada do movimento sindical progressista nos últimos anos da década de 1970. Os atores dessas lutas eram trabalhadores organizados dos setores de ponta do capitalismo brasileiro, concentrados em grande parte na região do $\mathrm{ABC}$ paulista. Esses novos setores (que vieram a ser conhecidos como o "novo sindicalismo", ou "combativos”) sustentaram a fundação de um partido dos trabalhadores, o PT, obtendo o apoio de setores da intelectualidade progressista, de setores progressistas da Igreja Católica (integrantes das comunidades eclesiais de base) e da "esquerda revolucionária" (trotskistas, comunistas revolucionários e herdeiros da "esquerda armada" dos anos 1960), extremamente críticos ao PCB. O PT logo se definiu como uma alternativa "à esquerda" dos pecebistas, assumindo um papel oposicionista mais radical, avesso ao diálogo com o regime - criticando o "reformismo" da linha pecebista.

No meio sindical, as diferenças se acentuaram. Desde as greves do final dos anos 1970, o PCB criticava o pretenso "radicalismo" e "voluntarismo" do "novo sindicalismo", enquanto este associava os pecebistas ao sindicalismo pré-1964, para eles "pelego" e "reformista". Tais posições acabaram levando os setores sindicais dos dois partidos a caminhos opostos, contribuindo para a formação de duas centrais sindicais: os petistas apoiaram decisivamente a fundação da Central Única dos Trabalhadores (CUT) em 1983, enquanto os pecebistas, por alegadas razões táticas, escolheram permanecer atrelados a setores conservadores do movimento sindical e participar da fundação da Central Geral dos Trabalhadores (CGT) em 1986. Aos pecebistas (que além de tudo fincavam raízes em setores mais "antigos" ou "tradicionais" da classe operária brasileira) pareceu mais seguro disputar espaço com os conservadores e fazer valer suas posições, buscando hegemonizar a CGT. A alternativa a isso seria conviver com os setores mais “combativos” que controlavam a CUT e possuíam, em relação ao PCB, a vantagem de um discurso igualmente progressista, mas calcado numa 
inserção já consolidada nos setores sindicais sobre os quais a CUT tinha ascendência. De qualquer forma, a ilusão da possibilidade de hegemonia (ou mera sobrevivência) pecebista na CGT levou o partido a atuar por vários anos numa central sindical dividida e progressivamente enfraquecida, enquanto a CUT (hegemonizada pelo PT) atravessou a década de 1980 em constante crescimento. ${ }^{15}$

Esses dois fenômenos - surgimento do "novo sindicalismo" e do PT - foram recebidos com extrema dificuldade pelos pecebistas. Especialmente o último se configurava como um fato novo na política brasileira: um partido de massas com forte ascendência operária, grande inserção nos movimentos sociais, relacionado aos setores mais pujantes do movimento sindical. Ou seja, um partido com grande potencial para ocupar exatamente o espaço que o PCB buscava hegemonizar desde sua fundação. Um adversário em potencial que poderia tornar-se um entrave ao projeto pecebista. Assim, os pecebistas nutriram um necessário respeito ao PT, ao mesmo tempo em que o acusaram de "sectarismo" ou "esquerdismo" em alguns momentos e de "socialdemocratismo" em outros. Os pecebistas iam reconhecendo aos poucos o crescimento e consolidação do PT (muitos, a princípio, apostavam em seu fracasso), ao mesmo tempo em que buscavam se diferenciar dele, declarando-se os verdadeiros representantes dos trabalhadores por sua "experiência”, "sensatez” política e a defesa aberta do socialismo. Tratava-se de uma maneira de manter a crença em dias melhores que possivelmente viriam com a legalidade e a disputa em campo aberto. Quando isso ocorresse (acreditava-se), o PCB poderia recuperar seus dias de glória.

Não foi o que se viu. O PT ocuparia o papel de partido hegemônico nas esquerdas e no movimento sindical que outrora havia sido do PCB, tornandose ainda uma real alternativa de poder - algo que o PCB, por contingências da política brasileira e de sua própria essência, nunca pôde ser. Assim, para muitos pecebistas ficou a percepção (correta, mas não pelos motivos apontados por eles) de que houve uma forte relação entre o surgimento do "novo sindicalismo" e do PT e o "ocaso" do PCB. É muito comum nos depoimentos colhidos a idéia de que houve um movimento consciente por parte do regime em retardar ao máximo a legalização do PCB, enquanto o PT, com a vantagem da legalidade, consolidava suas posições. Da mesma forma, o "novo sindicalismo" surgiria no espaço deixado pela repressão anterior ao sindicalismo e ao partido. Faz-se

\footnotetext{
${ }^{15}$ A respeito desse tema, cf. SANTANA, Marco Aurélio. Homens partidos. São Paulo: Boitempo, Rio de Janeiro: Unirio, 2001.
} 
questão de desmistificar a "novidade" do "novo sindicalismo" e a representação dos trabalhadores reivindicada pelo PT:

O Lula entra no movimento sindical via intervenção do sindicato. Essa história do novo movimento sindical foi em função do esvaziamento, do espaço deixado em branco pelos comunistas e trabalhistas na época. (...) O PT não era partido operário, ninguém fala isso! Naquela hora o movimento operário era aquele ali. Mas se o PCB fosse legalizado naquela altura vinha com toda a tradição, com todos os companheiros vindos do exílio que estavam espalhados por aí, a intelectualidade que era do partido... Isso tudo foi absorvido pelo PT. O partido estava legal, a gente não era legal. Não tinha espaço na política. ${ }^{16}$

Apesar de em parte distorcerem a realidade, a força contida em diversos depoimentos colhidos acerca do tema ao longo da pesquisa está na confirmação da importância atribuída à falta de representatividade dos pecebistas no renascente movimento sindical progressista e ao surgimento de um partido nos moldes do PT para o enfraquecimento do PCB. As explicações aventadas por esses atores nos dias de hoje não dão conta de tal fenômeno - ou pelo menos de seus principais fatores, já que algumas observações reproduzidas acima têm sua razão de $\operatorname{ser}{ }^{17}$ pelo menos enquanto fatores secundários. Mas, de qualquer forma, a simples necessidade de formulação dessas explicações (temperadas com variadas doses de ressentimento) aponta o golpe que representou para os pecebistas a ascensão de um movimento de trabalhadores indiferentes ou francamente hostis ao PCB e de um partido que se proclamava dos trabalhadores - igualmente indiferente ou mesmo hostil ao partido até então referido como a vanguarda da classe operária. Naquele momento, imensos setores do operariado rejeitavam aqueles que pretendiam representá-los. Certamente um duro golpe, mal assimilado até hoje, e determinante da visão negativa apresentada pelos depoentes sempre que se referem ao PT.

Naquele momento, os países socialistas já davam sinais de desgaste na opinião pública mundial (com episódios como a invasão do Afeganistão pela

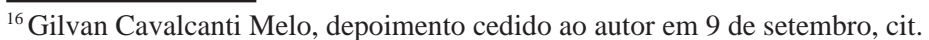

${ }^{17} \mathrm{O}$ PT de fato levou vantagem por ter sido legalizado antes do PCB, bem como a repressão sofrida pelos pecebistas ao longo da ditadura contribuiu para seu afastamento dos setores mais pujantes do sindicalismo.
} 
URSS em 1979 e a repressão na Polônia ao Sindicato Solidariedade) e claros sinais de dificuldades internas em diversos níveis. ${ }^{18}$ No entanto, o PCB continuava mantendo oficialmente sua imagem atrelada àquelas experiências: "A direção nossa, por uma série de razões - até pela luta com o Prestes - era uma direção afinada com a URSS - o Movimento Comunista Internacional era um elemento fundamental no jogo". ${ }^{19}$ A direção pecebista apoiava os regimes socialistas, chegando a defender categoricamente que "A União Soviética e os países do socialismo avançado constroem as bases materiais e culturais do comunismo". ${ }^{20}$ Pode-se entender o impacto que os pecebistas iriam vivenciar nos anos seguintes, enquanto um partido como o PT se posicionava criticamente em relação às experiências socialistas, evitando sua associação a "modelos” internacionais - como, de resto, a uma definição teórica mais restritiva.

\section{Entre a esperança e a decepção - o PCB na redemocratização (1984-1988)}

O PCB seguiu nos primeiros anos da década de 1980 em seu "delicado equilíbrio” entre atuação institucional e luta de massas, entre o enfrentamento ao regime e o temor de um retrocesso na transição democrática. Tal linha de atuação ficou clara nos momentos centrais da redemocratização, entre 1984 e 1985. Nos primeiros meses da campanha pelas Diretas Já para presidente (sustentada pela direção do PMDB e imediatamente apoiada pelo PT), uma ausência sentida foi a do PCB. O partido sempre havia defendido a proposta da Assembléia Constituinte - e mesmo após aderir à campanha, reafirmaria a centralidade da proposta de Assembléia Constituinte, à qual subordinava a luta por eleições diretas em todos os níveis. Além disso, é razoável supor que, naquele momento, lidando com suas lutas internas e retomando sua campanha pela legalidade, o partido estivesse num momento de paralisia decisória e temor em relação à possibilidade de um retrocesso na transição democrática, "motivado" pelas manifestações populares. Qualquer que tenha sido o motivo, o fato é que o PCB tardou a prestar apoio e a participar efetivamente do movimento, engajando-se nele apenas quando percebeu sua irreversibilidade.

\footnotetext{
${ }^{18}$ Cf. REIS FILHO, Daniel Aarão. Uma revolução perdida: a história do socialismo soviético. São Paulo: Fundação Perseu Abramo, 1997.

${ }^{19}$ Givaldo Siqueira, depoimento cedido ao autor em 9 de setembro de 2003, no Rio de Janeiro (RJ).

${ }^{20}$ Partido Comunista Brasileiro. Uma alternativa democrática para a crise brasileira, op. cit., p. 50.
} 
Com a derrota no Congresso Nacional da Emenda Constitucional pelas eleições diretas em todos os níveis, o partido afirmou não ter preconceito em relação à negociação. Com o crescente deslocamento da “luta” para a “negociação”, a opção mais viável passava a ser apoiar uma candidatura única de oposição no Colégio Eleitoral que se aproximava - o que o PCB fez sem titubear, seguindo sua divisa de "lutar para negociar, negociar para mudar”. Formada a Aliança Democrática (sustentada pelo PMDB e por dissidentes do regime reunidos na Frente Liberal), o PCB prestou apoio imediato à candidatura de Tancredo Neves e José Sarney, vitoriosa na votação indireta. Com o falecimento de Tancredo, o partido apoiou o governo encabeçado por Sarney (que meses antes era presidente do governista Partido Democrático Social - PDS) em seus primeiros anos e ocupou espaços na administração federal, passando para a oposição apenas em 1988.

Para uma melhor compreensão das razões da política pecebista naquele período, é importante lançar mão de seu programa recém aprovado no VII Congresso. Nele, afirmava-se que o processo político brasileiro poderia seguir três direções:

A primeira é a da regressão política, pela via do golpismo, objetivando a manutenção dos traços centrais do regime. (...) A segunda perspectiva, passível de ser conjugada com a primeira, e na qual investem setores ponderáveis que sustentam o projeto de auto-reforma do regime, encontrando ressonância nos segmentos mais débeis da frente democrática, é a da "conciliação nacional" - um pacto de elites que, contemplando reivindicações de setores da oposição burguesa, conduza a um entendimento pelo alto, capaz de articular um novo respaldo político e uma base social mais larga para o regime reformado. A terceira perspectiva, que os comunistas avaliam como a mais favorável para a evolução do processo brasileiro, aponta na direção de uma solução política negociada para os impasses atuais. Trata-se de, à base da pressão organizada das massas, conquistar as condições sociais e políticas - no plano do movimento social e no plano institucional - para ultrapassar o regime e sua orientação econômico-financeira recessiva através de negociações que incluam setores do governo, do regime e do PDS. ${ }^{21}$

${ }^{21}$ Ibid., p. 176. 
É razoável supor que, ao prestar apoio à Aliança Democrática, vários pecebistas entendessem que aquilo era a materialização desse terceiro caminho - o preferido pelo partido. No entanto, assim como na análise oficial do PCB a segunda alternativa era "passível de ser conjugada com a primeira”, parece ter escapado à compreensão pecebista naquele momento que a terceira opção também era passível de conjugação com a segunda - já que a realidade nunca é estanque a ponto de caber em esquematizações, por mais lúcidas que sejam. O processo brasileiro parece ter apresentado características dos dois últimos "tipos ideais" apresentados na análise pecebista: de fato ultrapassou o regime e em parte modificou sua política econômica, além de ter se dado de forma negociada e com a participação de setores do governo. Mas, ao mesmo tempo, não deixou de ser majoritariamente um pacto de elites, assumindo caráter de “conciliação nacional” (expressão utilizada por Tancredo em sua campanha), em parte exatamente pela insuficiente participação das massas no processo um fator importante para que o processo se desse da forma desejada pelo PCB - algo reconhecido pela própria análise do partido.

O que a maioria dos pecebistas não compreendeu em toda a sua extensão naquele momento foi a dimensão conservadora da transição brasileira. Pode-se recorrer aqui a Carlos Nelson Coutinho que apontou a redemocratização brasileira como uma "transição fraca". Havia um "risco contido nessa forma de transição relativamente 'negociada'. Nela se verifica sempre (...) a combinação de processos 'pelo alto' e de processos provenientes 'de baixo'; e, decerto, é o predomínio de uns ou de outros o que determina o resultado final". ${ }^{22}$ Como naquela transição predominaram as forças do "alto”, ela terminaria por

reproduzir, ainda que "atenuados" e "modernizados”, alguns dos traços mais característicos do tradicional modo "prussiano" e "passivo" de promover as transformações sociais no Brasil. Uma transição desse tipo - que poderíamos chamar de "fraca" - implicava certamente uma ruptura com a ditadura implantada em 1964, mas não com os traços autoritários e excludentes que caracterizam aquele modo tradicional de se fazer política no Brasil. ${ }^{23}$

\footnotetext{
${ }^{22}$ COUTINHO, Carlos Nelson. Democracia e socialismo, op. cit., p. 52.

${ }^{23}$ Ibid., p. 53.
} 
No entanto, malgrado o caráter conservador do novo regime, se completaria o longo processo de redemocratização, com o qual os pecebistas haviam contribuído com sua política de "frente democrática". Política que o partido, superado o regime ditatorial, manteve ao longo do que considerou um "período de transição" e que, assim como não vinha dando frutos mais práticos ao PCB nos últimos anos de autoritarismo, menos ainda os deu nos tempos da "Nova República". O autodenominado "artífice" da nova ordem (dissociada de qualquer tipo de "transição forte”) decaía, enquanto o então partido anti-sistêmico consolidava-se. O PT - que havia se posicionado claramente contra a "transição pactuada", contra o Colégio Eleitoral e, desde o primeiro dia, contra o governo Sarney - aparecia na nova fase democrática como o núcleo principal da oposição de esquerda e o único em condições de apresentar uma alternativa progressista ao novo regime. O aumento de uma difusa percepção de que os sonhos democráticos acalentados por tanto tempo como a "cura" dos males nacionais não se realizariam na "Nova República" só iria consolidar a hegemonia petista entre a esquerda e os trabalhadores organizados. Por seu turno, a cada greve que ocorria (em geral liderada por sindicalistas ligados à CUT) o PCB fazia uma série de objeções, temendo que uma radicalização dos movimentos populares pudesse desestabilizar o novo regime. O PCB se declarava o "artífice” da nova ordem por ter defendido a transição “negociada” desde seu início, mas se afastava cada vez mais das massas que julgava representar enquanto "partido da classe operária".

O PCB acabou assumindo - mesmo que não fosse essa sua intenção - um papel de "contenção" no movimento sindical. Por outro lado, a década de 1980 representou, de modo geral, um período de ascenso e radicalização das lutas sindicais no país - o que se depreende do maior número de greves, aumento do número de sindicatos e sindicalizados, ascendência do movimento sobre a chamada "grande política”, entre outros fatores. ${ }^{24}$ Sem dúvida, a CUT e o PT eram não somente importantes para esse ascenso, como se valeram dele para a consolidação de suas posições. "Mesmo que relativizada, posteriormente, por esses dois agentes, a estratégia de enfrentamento dava frutos importantes nos

\footnotetext{
${ }^{24}$ Cf. SANTANA, Marco Aurélio. Homens partidos, op. cit., bem como o artigo do mesmo autor intitulado Trabalhadores em movimento: o sindicalismo brasileiro nos anos 1980-1990. In: FERREIRA, Jorge, DELGADO, Lucilia de Almeida Neves (orgs.). O Brasil republicano - vol. 4, O tempo da ditadura. Rio de Janeiro: Civilização Brasileira, 2003.
} 
setores organizados da sociedade". ${ }^{25}$ Com o tempo, os pecebistas reconheceram que a CGT era hegemonizada por setores conservadores, "pelegos” e “cupulistas”, enquanto progressivamente se deu a aproximação entre as propostas sindicais cutistas e as defendidas pelo PCB. A central progressivamente abandonou a defesa da pluralidade sindical (execrada pelo PCB por seu potencial de pulverização e enfraquecimento do movimento), moderou sua defesa exacerbada da utilização da greve como instrumento de luta, substituindo progressivamente o perfil "combativo" pelo "propositivo".

Mais uma vez a política geral pecebista influiu fortemente em sua intervenção sindical. Novamente, porém, alguns sindicalistas do partido na prática encontraram outro caminho ao permanecerem ligados à CUT, exercendo assim certa autonomia e nunca deixando de reivindicar o apoio oficial do partido àquela central. No entanto, assim como a política geral dos dois partidos dificultava a aproximação entre suas bases sindicais, a proposta de filiação à CUT só ganharia força a partir do momento em que o PCB assumisse postura mais independente em relação ao governo da Nova República (1988). Mesmo assim, ainda seriam necessários cerca de dois anos para a vitória definitiva da proposta sindical mais progressista no seio do PCB. Enquanto isso, o partido seguiria amargando derrotas atrás de derrotas no movimento. Por um lado, perderia espaço para setores cutistas. Por outro, seu espaço no interior da CGT seria progressivamente dilapidado pelos conservadores, hegemonizados a partir de agora pelo "sindicalismo de resultados".

O PCB vinha de trinta e sete anos de ilegalidade. Nesse período, viveu situações diversas, que iam desde a "semilegalidade" até a mais violenta repressão (que quase extinguiu o partido), dificuldades que tiveram seu peso - ainda que secundário - no enfraquecimento do partido. Depois de intensa campanha e negociação pela sua legalização (iniciada em 1980, paralisada com a repressão policial ao VII Congresso no final de 1981 e retomada em 1983), finalmente chegava o tão aguardado momento da legalidade. O PCB finalmente podia mostrar sua face à sociedade, emergir depois de décadas de perseguições. Esse momento histórico trouxe novo ânimo à maioria dos pecebistas e renovou as esperanças de uma retomada do poderio do velho partido. Porém, como temos visto até aqui, os tempos eram difíceis para o PCB. Os primeiros resultados

${ }^{25}$ SANTANA, Marco Aurélio. Homens partidos, op. cit., p. 253. 
eleitorais na legalidade foram muito aquém do esperado, o que começaria a minar a autoconfiança propagandeada pela direção pecebista.

O tom geral de otimismo e autopromoção da direção iria a partir dali iniciar uma lenta, mas constante inflexão. Em algum tempo, o PCB se assumiria como um partido em profunda crise, em busca de uma saída. Algo que militantes descontentes com os rumos da agremiação já haviam apontado anos antes, a partir de óticas variadas, e que pecebistas não afinados com o discurso da direção continuavam a repercutir dia após dia. $\mathrm{O}$ resultado eleitoral era apenas mais um entre os aspectos mais visíveis de uma crise geral - ideológica, organizativa e representativa - que o partido vivia. Um período de tantas dificuldades e incertezas que é lembrado por ex-pecebistas de maneira radicalmente negativa: “A referência da esquerda era o PT, não éramos mais nós. Tanto que quando o PCB foi legalizado já estava praticamente morto, um partido que nasceu morto". ${ }^{26}$

Em 1987, foi realizado o VIII Congresso (extraordinário) do PCB. As discussões públicas deflagradas pelo processo congressual, entretanto, demonstram que o partido permanecia dividido, e de maneira tão profunda que a situação tendia a se cristalizar: "quando chegou o VIII Congresso a luta já estava bastante acirrada, aí já ficava claro que havia um divisor de águas realmente, o choque das idéias se refletia na realidade política, no movimento sindical, mostrava claramente que a rigor já havia dois partidos". ${ }^{27}$ A partir dali começava a se definir com clareza um grupo contrário ao teor das transformações que o partido vivenciava. $\mathrm{O}$ recorrente dilema do $\mathrm{PCB}$ entre ser o partido da revolução ou das reformas, da classe operária ou do "povo brasileiro", aprofundava-se nesse momento.

Começou nesse momento também o debate no interior do PCB acerca da perestroika e da glasnost - e pode-se notar um claro interesse da maioria da direção nesse processo, visivelmente alimentado por ela. As transformações em curso na URSS permitiam que se acelerassem processos já em andamento no seio do $\mathrm{PCB}$, e que viessem à tona sentimentos adormecidos. O partido, que já vinha progressivamente se transformando, assumiria então algumas novas posições em grande parte motivadas pelas mudanças do "socialismo real". Um sinal dessa dinâmica pode ser encontrado no seguinte depoimento:

\footnotetext{
${ }^{26}$ Gilvan Cavalcanti Melo, depoimento cedido ao autor, cit.

${ }^{27}$ Zuleide Faria de Melo, depoimento cedido ao autor, cit.
} 
No PCB a perestroika e a glasnost foram recebidas em geral com apoio. Houve evidentemente certo setor que tinha desconfianças, muitos foram terminar nesse PCB aí... (...) Mas a maioria do partido, a sua liderança, fizemos da perestroika e da glasnost um elemento importante para a transformação interna (...). E isso foi um elemento importante na consolidação da viragem que o partido vinha dando (...) porque tirou um elemento de prisão, um obstáculo à nossa política interna. A gente avançava e tinha que ficar medindo passos em relação ao que os companheiros soviéticos iam dizer. E a gente também todo educado nessa idéia de que eles deviam estar mais certos do que nós. Isso foi uma coisa importante, porque removeu, passou a não ter mais uma camisa-de-força internacional. ${ }^{28}$

Esse depoimento dá a entender que a divisão que ia se delineando no partido se mantinha no que tange à aceitação ou não dos “ideais da perestroika". Por esse raciocínio, os que vinham aproximando o partido na prática de posições socialdemocratas abraçaram efusivamente a perestroika. Enquanto isso, os pecebistas contrários àquele projeto por qualquer motivo teriam recebido os ideais da perestroika com variados graus de desconfiança. Tal discurso serve ao universo das disputas políticas, mas deve ser desmistificado pelo pesquisador - como sempre, a realidade suplanta qualquer esquema binário de interpretação. Neste sentido é significativa a declaração abaixo, proferida por uma das representantes do grupo que mais tarde "reconstruiu" o PCB:

Eu acho que o Gorbachev realmente nos dois ou três primeiros anos de governo dele enganou direitinho a todos nós. (...) ele dizia uma coisa que parecia ser verdade: o lema era "mais democracia para mais socialismo". E a verdade não era essa: era menos democracia e menos socialismo. Só que ele conseguiu envolver isso aí num discurso tão bem elaborado - que ele é competente, disso aí não tenho dúvida nenhuma, é um salafrário, traidor, mas o discurso dele era muito atraente. ${ }^{29}$

Portanto, a receptividade nas fileiras pecebistas à nova política soviética parece ter sido ampla a princípio. Descontado o sentimento de "russofilia", as diferentes correntes conseguiam se identificar com um ideal caro à tradição

\footnotetext{
${ }^{28}$ Givaldo Siqueira, depoimento cedido ao autor, cit.

${ }^{29}$ Zuleide Faria de Melo, depoimento cedido ao autor, cit.
} 
socialista: “mais democracia para mais socialismo”. Uma oposição aberta a tal programa só iria se delinear quando dois fatores começassem a ficar claros aos atores envolvidos: em primeiro lugar, que as reformas implementadas na URSS com o objetivo declarado de recuperar e aprofundar o "socialismo real", ao invés de "curar o doente" estavam acelerando sua morte; em segundo lugar, que os ideais propagados pela perestroika vinham servindo de justificativa para transformações no PCB que poderiam, em última instância, levá-lo à extinção.

No início de 1988, sua Executiva Nacional determinou que "o PCB assumirá uma firme postura de oposição à atual orientação do governo Sarney". ${ }^{30}$ Justificou-se tal posição com argumentos como a progressiva hegemonia dos setores conservadores no governo e também com a proximidade do término da transição democrática. ${ }^{31} \mathrm{Na}$ concepção dos pecebistas, o período se encerraria com a promulgação da nova Carta, em 1988. Vale destacar que a defesa de uma Assembléia Constituinte havia sido uma proposta central na política "frentista” do PCB. Para a maioria dos pecebistas, a Constituinte (apesar de não ter assumido o formato de uma Assembléia Constituinte, mas de um Congresso Constituinte) era carregada de simbolismo e seu encerramento em 1988 marcou para o PCB o fim do processo de transição democrática.

O PCB teria extrema dificuldade em formular uma nova política, em meio a suas dilacerantes disputas internas. Num extremo, alguns setores do partido defenderiam o abandono do "frentismo" pecebista (que já havia se tornado um forte elemento de sua identidade), optando por uma aliança à esquerda, ao lado do PT. Em outro, defenderia uma "frente democrática", na prática uma manutenção da política antiditatorial em tempos democráticos (guindada finalmente a estratégia do partido). Determinando essa divisão, duas visões distintas: a primeira valorizando preferencialmente o conteúdo classista e revolucionário do partido e sua reinserção no movimento sindical progressista, elementos que vinham se perdendo; a segunda associando-se à idéia do PCB popular, democrático e reformador, componentes sempre presentes no partido, mas nunca com tanta força quanto agora. Não se encontraria uma síntese. Em breve, nem mesmo a preservação do partido seria possível - processo que em

\footnotetext{
${ }^{30}$ Novo caminho na oposição. Voz da Unidade n. ${ }^{\circ} 381$ (05/02/1988), p. 3.

${ }^{31}$ Tal posicionamento representou também um fortalecimento no interior do partido de setores à esquerda - além da crescente dificuldade em caracterizar o governo de transição como minimamente progressista.
} 
seus últimos momentos guardaria importantes relações com o desdobramento da crise nos países socialistas.

\section{Divisão da utopia - o destino do PCB em disputa (1989-1992)}

Nesse momento, o processo de definhamento do partido chegou ao ápice, concomitante ao colapso do "socialismo real". Constatada a gravidade da situação, foram levantadas numerosas possibilidades para a sua superação e, entre todas, sairia "oficialmente" vitoriosa a da transformação do PCB em um novo partido, declarado "herdeiro" de parte de suas tradições. Tal processo levou à "diáspora pecebista": um grupo de militantes permaneceria organizado enquanto "PCB", buscando reproduzir (ou "resgatar") os aspectos mais "revolucionários" de sua identidade; outros seguiriam para o PT (consolidado naquele momento como o maior partido da esquerda brasileira); alguns buscariam o reencontro com a identidade comunista no Partido Comunista do Brasil (PC do B); e, principalmente, muitos abandonariam a militância partidária.

Nesse momento, a relação de maior destaque se dá entre a derrocada do “socialismo real” no Leste Europeu e desintegração da URSS e as proposições pelo fim do PCB. Desde 1987, como foi dito, parte da direção pecebista conscientemente se aproveitou dos "novos ventos" internacionais para levar adiante transformações almejadas por certo setor do partido. Em primeiro lugar, aproveitando-se do alargamento da "camisa-de-força" internacional. O partido não tinha seus rumos determinados pelas posições da URSS e do Partido Comunista da União Soviética, ${ }^{32}$ mas vivenciava limitações de ordem simbólica dadas por sua filiação internacional. Em segundo lugar, brandindo as idéias simbolizadas pela perestroika na luta interna. Procurava associar-se o PCB à perestroika: "a influência aqui no partido é evidente que se expressou porque a gente tinha a cultura de que tudo que partia da URSS era bom! Quando o Gorbachev assumiu, nós também... A direção assumiu praticamente essa visão também. (...) O 'oba-oba' era geral”! ${ }^{33}$

Houve, então, o interregno da campanha presidencial de Roberto Freire. A princípio, apenas uma tentativa de afirmação do partido nas esquerdas e no

\footnotetext{
${ }^{32}$ Como parte da historiografia tradicional acerca do tema considerava. Cf. entre outros CHILCOTE, Ronald. Partido Comunista Brasileiro: conflito e integração (1922-1974). Rio de Janeiro: Graal, 1982.

${ }^{33}$ Gilvan Cavalcanti Melo, depoimento cedido ao autor, cit.
} 
campo político como um todo e uma tentativa de unificação de suas próprias fileiras, a campanha foi assumindo aos poucos uma aura de "novidade" para alguns setores da sociedade, em especial da intelectualidade. Teve, sem dúvida, uma força simbólica maior que o resultado final alcançado: o oitavo lugar, com cerca de 1\% da votação ou 769.000 votos. Expressões como "nova esquerda", "esquerda moderna" e "socialismo democrático" foram amplamente empregadas, sendo associadas a Freire e ao PCB. O candidato e seu vice Sérgio Arouca defenderam sistematicamente um "novo socialismo", democrático, defensor das liberdades, enquanto algumas críticas mais contundentes a países socialistas como Cuba e China foram proferidas. Idéias-força do "socialismo real", como a estatização, foram relativizadas. A crise do socialismo, que deu seus passos decisivos em plena campanha de Freire, certamente serviu para reforçar e definir algumas das posições assumidas ao longo daquela campanha que deflagrou o processo de transformação do PCB nos anos seguintes. Porém, tais posições refletiam em boa parte as mudanças pelas quais o partido vinha passando nos últimos anos e representavam significativos setores pecebistas.

Nesse contexto, a polêmica acerca da atuação sindical do PCB, que se arrastou por toda a década de 1980, sendo abafada em vários momentos, agora era retomada de forma irresistível. A realidade havia demonstrado o equívoco da atuação do partido junto aos setores mais conservadores do movimento sindical. A CGT (na qual os pecebistas buscavam levar adiante sua política de "unidade") serviu de "celeiro" a um "sindicalismo de resultados", em tudo diferente do que o partido defendia. A hegemonia da central, que os pecebistas esperavam conquistar derrotando os tradicionais, havia passado para as mãos de setores novos, forças conservadoras modernas, adaptadas à nova realidade do país. Estas afastaram da central tanto os tradicionais quanto os pecebistas (ironicamente companheiros dos "pelegos" também na derrota). Por seu turno, a atuação prática da CUT (naquele momento consolidada como central hegemônica, contrariando as previsões de muitos pecebistas de que ela não teria vida longa), já não diferia muito daquilo que o PCB defendia para o movimento sindical. Ao mesmo tempo, a central vinha perdendo em "combatividade”. Sua atividade se moderava, lançando as bases para sua atuação defensiva nos anos 1990, focada na questão do emprego. ${ }^{34}$ Tal moderação pode ser explicada em

\footnotetext{
${ }^{34}$ Cf. SANTANA, Marco Aurélio. Trabalhadores em movimento: o sindicalismo brasileiro nos anos 1980-1990, op. cit.
} 
grande parte pela crise mundial das esquerdas e pela ascensão do neoliberalismo, mas também guarda relação com a própria dinâmica da CUT e do PT.

A história da atuação sindical pecebista naquela década é basicamente uma sucessão de derrotas: a perda de vários sindicatos para setores cutistas que depois os filiavam à central, bem como a predileção dos novos sindicatos progressistas que surgiam pela filiação à CUT. Os espaços dos pecebistas se reduziam na CGT, mas principalmente fora dela. Em 1989, a direção sindical pecebista buscou ainda uma "solução intermediária": a atuação "eqüidistante" do partido, sem a opção definitiva por uma das centrais. Tal "solução" perdurou oficialmente até o ano seguinte, mas, na prática, os setores cutistas do PCB já eram amplamente majoritários e a luta pela entrada na central acabou saindo vitoriosa do Encontro Nacional de Sindicalistas do PCB (Praia Grande, SP, 20 e 21 de outubro de 1990). Nele, finalmente optou-se pelo abandono da "política de eqüidistância" e pela atuação na CUT, decisão tomada por ampla maioria - apesar de alguns resistentes, argumentando que aquela reunião não tinha caráter deliberativo, tendo sido convocada apenas para discutir a crise vivida pelo partido e a eleição de sua direção sindical. De fato, os setores cutistas, cansados de indefinição e certos de sua maioria, impuseram a discussão e votação daquela proposta - numa espécie de rebelião das bases. Foi de fato uma vitória dos setores "à esquerda" do partido, mas na prática tal decisão não passava de "letra-morta". Apesar da atuação na CUT estar agora oficializada, o grau de dissensão no PCB era tal que alguns militantes permaneceram na CGT e muitos participaram das articulações para a fundação da Força Sindical (criada pelos “sindicalistas de resultados” em 1991). Àquela altura, as divisões no partido se mantinham e se aprofundavam independentemente da posição oficial que fosse tomada.

Após as eleições presidenciais de 1989 (e especialmente após as eleições de 1990, na qual o PCB teve novamente resultados ínfimos), se deu um verdadeiro florescimento da diversidade nas fileiras pecebistas - talvez a maior em toda a trajetória do partido - na esteira da convocação do IX Congresso, realizado em 1991. Configurou-se, a princípio um amplo espectro de posições que foi desde as abertamente social-democratas (como a do dirigente Jarbas de Holanda, que sairia do PCB no início de 1991 apontando o Partido da Social Democracia Brasileira como “alternativa de esquerda moderna” e a Força Sindical como "opção de sindicalismo plural”) ${ }^{35}$ num extremo, passando por

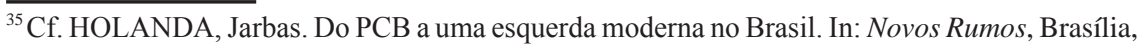


propostas de fusão com o Partido Socialista Brasileiro, diluição no PT, extinção do partido, formação de uma nova agremiação, resgate do "revolucionarismo perdido" do PCB, até chegar ao outro extremo do espectro, habitado por militantes que não aceitavam maiores revisões da trajetória do partido e iriam se abrigar no PC do B (entre esses, os mais destacados eram os dirigentes Juliano Siqueira e Francisco Milani que deixariam o partido logo após o IX Congresso).

Nesse meio-tempo, boa parte do núcleo dirigente assumiu abertamente a luta pela transformação completa do partido, baseada na crítica da experiência socialista, dos valores leninistas, do centralismo, da burocratização, do conceito de vanguarda, do partido único, da ditadura do proletariado. Transformação calcada no valor estratégico da democracia e na superação da dicotomia entre reforma e revolução. Grande parte dos militantes pecebistas não concordava com tais posições. A esses, indistintamente, os setores majoritários na direção rotularam de "conservadores". No entanto, deve-se frisar que

A crítica a essas teses nem sempre representou uma defesa irrestrita da ortodoxia. Será a maior ou menor ênfase na crítica à cultura e prática ortodoxa que determinará a heterogeneidade da oposição e os diferentes rumos que seus membros tomarão. Na dissidência havia o desejo de renovação - com caráter e conteúdo diferenciado da renovação modernizante da maioria capitaneada por Freire. Havia ainda elementos autocríticos em relação à práxis do partido nos últimos anos. Embora mantivessem conceitos e concepções ortodoxas, os dissidentes elaboraram uma reflexão crítica sobre o marxismo-leninismo e as experiências do socialismo real. ${ }^{36}$

Durante o processo congressual, a pluralidade de concepções do partido terminou por se agregar em três tendências. ${ }^{37}$ A maioria se agrupou em torno de

\footnotetext{
Instituto Astrogildo Pereira, n. ${ }^{\circ}$ 20, 1991.

${ }^{36}$ SILVA, Antônio Ozaí da. Os comunistas diante do muro: o marxismo-leninismo entre a negação e a afirmação da tradição stalinista. In: Diálogos. Maringá: Universidade Estadual de Maringá, v. 3, 1999.

${ }^{37} \mathrm{O}$ primeiro embate pelo controle do partido se daria na definição da estruturação do congresso. Um grupo capitaneado por Freire defenderia a abertura total do congresso a não-filiados e a realização de "fóruns socialistas” reunindo indivíduos (pecebistas ou não) interessados na constituição de uma "nova esquerda", podendo eleger representantes para a etapa final do congresso. Por fim, seria aprovado um meio-termo: direito de discussão e voto para os participantes de "fóruns socialistas” não-filiados ao PCB na discussão da Resolução Política, mas não no balanço do trabalho da direção e eleição da nova (o direito de voto a não-filiados seria aprovado meses depois para o $\mathrm{X}$ Congresso, o que evidencia a rápida mudança da correlação de forças). Além disso, pela pri-
} 
Freire, Arouca e Salomão Malina e se apresentou no congresso sob a alcunha de "Socialismo e democracia”, defendendo "a renovação radical do partido. Isto significava abandonar a tradicional concepção de partido de quadros e da ditadura do proletariado e o desafio de construir uma nova teoria e organização partidárias. A maioria da DN [Direção Nacional] coloca em xeque a existência do PCB, seu nome, seus símbolos e a tradição histórica que estes encerram”. ${ }^{8}$ A oposição tachada de "ortodoxa” se agrupou na tendência "Fomos, somos e seremos comunistas”, capitaneada por Oscar Niemeyer, Francisco Milani, Horácio Macedo, entre outros. Defendia (ou buscava "resgatar") o caráter revolucionário do partido, sua estrutura leninista de organização e seus símbolos - muitos deles, porém, assumiam uma postura crítica em relação à experiência socialista e a alguns aspectos do marxismo-leninismo. Por fim, outro grupo se configurou como uma "terceira via" entre o que classificava como "social-democracia" da primeira e "ortodoxia stalinista” da segunda. Era a "Política de esquerda pelo novo socialismo” (liderada por Domingos Tódero) que defendia a manutenção do nome e dos símbolos do partido, mas pugnava pela aprovação de boa parte das propostas transformadoras defendidas pela maioria - dando-lhes, no entanto, um caráter mais definidamente socialista.

O IX Congresso terminou com a esperada vitória do grupo de Freire (que foi eleito presidente do partido), porém por uma margem apertada: 53\%, contra 36\% da chapa "Fomos, somos e seremos comunistas" e 11\% da chapa "Política de esquerda pelo novo socialismo". As oposições somadas chegaram perto da maioria, inviabilizando momentaneamente o projeto de substituição imediata do PCB por um novo partido, com novo formato e sem um credo oficial marxista. As oposições obtiveram outra significativa concessão da maioria quanto à definição das forças políticas que poderiam integrar o "novo bloco político" proposto pela direção pecebista (como caminho para a construção de um novo pólo de poder contraposto à hegemonia conservadora vigente): "fizeram uma composição grande que a gente sabia que ia durar muito pouco tempo. O Roberto [Freire] na época fez uma 'concessãozinha' e botou 'frente democrática, progressista e de esquerda' [a princípio seria apenas democrática], e aí mudou

meira vez setores do partido poderiam se apresentar como tendências no congresso, com chapas próprias - a direção seria escolhida proporcionalmente aos votos de cada grupo.

${ }^{38}$ SILVA, Antônio Ozaí da, op. cit. 
tudo. Servia para os dois lados. Um defendia a democracia e o outro defendia a frente de esquerda" ${ }^{39}$

Pouco depois, acontecimentos relacionados ao "socialismo real” (mais especificamente à URSS) seriam mais uma vez utilizados como pretextos para ações pecebistas, servindo então de "justificativa internacional" para a convocação do congresso (o X) destinado a encerrar a trajetória pecebista. $\mathrm{O}$ golpe de agosto de 1991 e os movimentos precipitados por ele - a perseguição aos comunistas soviéticos, o recrudescimento de sentimentos chauvinistas, a desintegração soviética - reforçaram as posições "transformistas" no interior do PCB (sendo utilizadas nesse sentido pelos defensores dessas posições). Com essa justificativa - somada ao aprofundamento da crise brasileira ao longo daquele ano -, a maioria da direção pecebista decidiu acelerar o processo de mudanças, convocando “o X Congresso do PCB, em caráter extraordinário, a se realizar o mais breve possível, para discutir a constituição da nova formação política - o que inclui a nova forma-partido, seu nome e símbolo”. ${ }^{40}$ A decisão pela convocação imediata de mais um congresso partidário parece ter sido tomada intempestivamente (talvez com a pressa necessária para se aproveitar um momento claramente favorável ao desejo de mudanças no partido), a se julgar pelo seguinte depoimento:

o congresso de mudança de nome foi uma coisa intempestiva. Saiu sem grande preparação. (...) o Roberto Freire convocou o congresso para mudar o nome do partido. Nós da executiva discutimos, concordamos inteiramente com o Roberto, então fomos para um congresso onde a questão era não as grandes transformações, ficou uma coisa retida, não houve uma grande acumulação nem dentro nem fora do partido. ${ }^{41}$

A oposição, dividida e sem poder contar com a estrutura e a preparação necessária (ao mesmo tempo em que setores dela aderiam ao PC do B e ao PT), lançou-se como pôde ao combate sem tréguas pela preservação do partido. $\mathrm{Na}$ seqüência da convocação do X Congresso, 29 membros da direção pecebista

\footnotetext{
${ }^{39}$ Gilvan Cavalcanti Melo, depoimento cedido ao autor, cit.

${ }^{40}$ Diretório Nacional do PCB. Resolução política do PCB (01/09/1991). In: Partido Comunista Brasileiro. IX Congresso do Partido Comunista Brasileiro - caminhos e descaminhos. Florianópolis: 1991, p. 81.

${ }^{41}$ Givaldo Siqueira, depoimento cedido ao autor. cit.
} 
lançaram um comunicado, manifestando "seu mais veemente repúdio à postura liqüidacionista da maioria do Comitê Central, que convocou um Congresso Extraordinário, com a finalidade exclusiva de tentar extinguir o nosso partido, criando outro em seu lugar", ${ }^{42}$ denunciando "que essa convocação representa a capitulação ante a histeria anticomunista surgida após os acontecimentos da União Soviética e um golpe contra as deliberações do IX Congresso, recém realizado" ${ }^{43}$ A partir dali, não se mediriam palavras e ações, as partes em contenda perderiam definitivamente o sentimento de pertencimento à mesma organização:

definimos que (...) nós íamos começar a nos organizar, a briga ia ser agora pra valer e ia ser de forma clara, insofismável (...). Desse período até o X Congresso foi uma briga de foice no escuro. Você pode imaginar o que é uma briga de foice no escuro... (...) Aí era pra valer, era briga mesmo, sem princípio, sem nenhum compadrio (...) nós tínhamos delegados (e nisso a História ainda vai nos fazer justiça) que eram militantes do partido. Não era o caso do Roberto Freire. ${ }^{44}$

Esta é a mais comum contestação do grupo minoritário em relação ao processo congressual. Deu-se aos não-filiados o direito de voto integral (quando este havia sido apenas parcial no congresso anterior) e os delegados ao congresso foram definidos nos chamados "fóruns socialistas", abertos à participação de todos os interessados. Sem dúvida, tal estratagema consolidou a vantagem dos setores majoritários - mas não se pode afirmar categoricamente que uma estruturação diferente do congresso pudesse modificar seus resultados, já que o momento era favorável aos que pretendiam abandonar antigos paradigmas.

O processo congressual, sem maiores discussões senão acerca da mudança do partido, foi naturalmente polarizado entre apenas duas chapas: "Movimento socialismo e democracia”, dos chamados "renovadores modernizantes"; e "Renovação revolucionária", dos que receberam a pecha de "ortodoxos". Vale notar, curiosamente, que ambos se definiram pela "renovação". Chegado o momento decisivo do X Congresso (sua fase final se realizou de 24 a 26 de janeiro de 1992), os "renovadores revolucionários" detinham cerca de um terço da representação. Dessa forma, não lhes restou alternativa - haja vista que não

\footnotetext{
${ }^{42}$ Partido Comunista Brasileiro. IX Congresso do Partido Comunista Brasileiro, op. cit., p. 83.

${ }^{43}$ Idem.

${ }^{44}$ Zuleide Faria de Melo, depoimento cedido ao autor, cit.
} 
havia mais conciliação possível entre as duas concepções - a não ser abandonar o congresso, seguindo para um "congresso paralelo" já previamente marcado de "reconstrução" do PCB. A maioria congressual, agora solitária, decidiria pela fundação do Partido Popular Socialista (PPS). O "racha" estava caracterizado.

Para além do nascimento do PPS e de outro partido que lutaria nos anos seguintes com sucesso pela sua legalização enquanto "PCB", é necessário registrar a verdadeira "diáspora" que se deu nesse momento - desde a preparação do IX Congresso até o encerramento do X. Um grande número de pecebistas decidiu seguir sua militância (ou reinventá-la) numa gama de outras organizações, mas fundamentalmente no PT e no PC do B. Além disso, deve-se lembrar do número incomensurável de pecebistas que abandonaram a atuação política, entre os quais muitos, desgostosos, perderam a referência de toda uma vida. Deu-se uma pulverização da militância pecebista (algo que de certa forma já vinha se dando, ainda que lentamente, durante todo o período analisado nestas páginas), de sua identidade, de sua memória. Caberia a partir de então a seus diversos “herdeiros” a reivindicação, reprodução, renovação e manipulação de sua identidade esfacelada.

\section{Conclusão}

Ao longo do período analisado, o partido foi perdendo progressivamente espaço nas esquerdas e nos movimentos sociais, enquanto o PT e a CUT ascendiam. Com a legalidade em 1985, os pecebistas foram obrigados a amargar ínfimos resultados eleitorais. Tiveram que conviver com crises internas que custaram esporádicas cisões e com a crise que acometia o "mundo socialista" e o pensamento marxista em geral. A derrocada do chamado "socialismo real" (1989-1991) seria o golpe final para o partido que, devido às experiências acumuladas nos anos anteriores, optou pela sua transformação em uma nova agremiação, o PPS - equilibrado entre referências a uma "nova esquerda” e a "herança" (selecionada) de um rico passado. Enquanto isso, um grande número de pecebistas decidiu seguir sua militância ou reinventá-la numa gama de outras organizações, enquanto alguns buscam "reconstruir o PCB".

O PCB - dividido ao longo de sua trajetória entre a reforma e a revolução, entre ser representante do operariado ou do povo brasileiro, valorizar a demo- 
cracia e o caminho pacífico ou a ditadura do proletariado e a insurreição ${ }^{45}$ - não soube superar a "divisão de sua utopia" quando a nova configuração do país exigia uma opção mais clara pela "modernização" do partido. Assim, a persistência de concepções e práticas não adaptadas à nova realidade brasileira (não superadas graças à sua persistente dicotomia que se manifestou com violência em seus últimos momentos) é a principal causa de sua crise.

A isso se juntaram as dificuldades pecebistas em lidar com a transição negociada (à qual terminou atrelado em posição subalterna), uma transição “fraca”, com predominância dos interesses conservadores. Com isso, o partido demorou muito a apoiar as Diretas Já (paralisado pelas suas disputas internas e defensor até o fim da proposta de Constituinte), apoiou a solução do Colégio Eleitoral e a Aliança Democrática, mas ficou subordinado àquele projeto sem maior independência, e depois disso também ao Governo Sarney. Já o PT e a CUT, assumindo posição radicalmente oposta à forma como se deu a transição e à "Nova República", se viabilizaram enquanto forças hegemônicas, respectivamente, nas esquerdas e no movimento sindical progressista. Por fim, outro fator importante (mas que teve seus momentos decisivos no período posterior ao analisado nesse trabalho) foi a crise e derrocada do mundo socialista, o que terminou por reforçar e legitimar tendências e posições já presentes no PCB, numa espécie de retirada da "camisa-de-força" internacional que o partido até então "simbolicamente" vestia.

\section{Referências bibliográficas}

BRANDÃO, Gildo Marçal. A esquerda positiva: as duas almas do Partido Comunista. São Paulo: Hucitec, 1997.

CAPISTRANO FILHO, David et. al. (orgs.). Há o que fazer - a esquerda na Nova República. São Paulo: Hucitec, 1986.

CARONE, Edgard. O PCB (v. 3 - 1964-1982). São Paulo: Difel, 1982.

CHILCOTE, Ronald. Partido Comunista Brasileiro: conflito e integração (19221974). Rio de Janeiro: Graal, 1982.

COUTINHO, Carlos Nelson. Democracia e socialismo. São Paulo: Cortez, 1992. Gramsci - um estudo sobre seu pensamento político. Rio de Janeiro: Civilização Brasileira, 1999.

\footnotetext{
${ }^{45}$ A respeito dessa dicotomia, cf. BRANDÃO, Gildo Marçal. A esquerda positiva: as duas almas do Partido Comunista. São Paulo: Hucitec, 1997.
} 
HOLANDA, Jarbas. Do PCB a uma esquerda moderna no Brasil. In: Novos Rumos. Brasília: Instituto Astrogildo Pereira, n. ${ }^{\circ}$ 20, 1991.

MALINA, Salomão. O socialismo em renovação - resumo de intervenções e artigos sobre a conjuntura internacional. Brasília: Novos Rumos, 1989.

NOGUEIRA, Marco Aurélio et. al. (orgs.). O PCB em São Paulo: documentos (1974-1981). São Paulo: Lech, 1981.

PANDOLFI, Dulce. Camaradas e companheiros: história e memória do PCB. Rio de Janeiro: Relume-Dumará, 1995.

PARTIDO COMUNISTA BRASILEIRO. Uma alternativa democrática para a crise brasileira. Novos Rumos, São Paulo, 1984.

IX Congresso do Partido Comunista Brasileiro - caminhos e descaminhos. Florianópolis, 1991.

PARTIDO DOS TRABALHADORES. Resoluções de encontros e congressos (1979-1998). São Paulo: Fundação Perseu Abramo, 1998.

POLLACK, Michael. Memória, esquecimento, silêncio. Estudos Históricos. Rio de Janeiro: vol. 2, n. ${ }^{\circ}$ 3, 1989.

REIS FILHO, Daniel Aarão. Uma revolução perdida: a história do socialismo soviético. São Paulo: Fundação Perseu Abramo, 1997.

RODRIGUES, Leôncio Martins. PCB: os dirigentes e a organização. In: FAUSTO, Boris (dir.). História geral da civilização brasileira, tomo 3, vol. 3: o Brasil republicano - sociedade e política (1930-64). Rio de Janeiro: Bertrand Brasil, 1996.

SANTANA, Marco Aurélio. Homens partidos, São Paulo: Boitempo, Rio de Janeiro: Unirio, 2001.

Trabalhadores em movimento: o sindicalismo brasileiro nos anos 1980-1990. In: FERREIRA, Jorge, DELGADO, Lucilia de Almeida Neves (orgs.). O Brasil republicano - v. 4. Rio de Janeiro: Civilização Brasileira, 2003.

SILVA, Antônio Ozaí da. Os comunistas diante do muro: o marxismo-leninismo entre a negação e a afirmação da tradição stalinista. In: Diálogos. Maringá: Universidade Estadual de Maringá, v. 3, 1999.

VIANNA, Luiz Werneck. A revolução passiva - iberismo e americanismo no Brasil. Rio de Janeiro: Revan, 1997. 